\title{
How the Profile of Student's Views on the Nature of Science and Technology?
}

\author{
Atep Rian Nurhadi*, Hernani Hernani, Iqbal Musthapa, Raden Devita Feliyanthi Somadipraja \\ Department of Chemistry Education \\ Universitas Pendidikan Indonesia \\ Bandung, Indonesia \\ *ateprian@upi.edu, hernani.kimia@gmail.com
}

\begin{abstract}
This study aims to provide a profile of students' views on the nature of Science and Technology or VNOST as a basis for the development of didactic designs that can teach aspects of technology in high school chemistry learning. This study involved 196 students who were randomly selected from grades XI from one of the secondary schools in Bandung. The modified VNOST questionnaire was used as a research instrument consisting of four aspects, namely: 1) the view of science, the purpose of science, the purpose of scientific research, 2) the view of technology, 3) the view of scientific knowledge and scientific theory, and 4) the view of the relationship between science, technology, and society. Each statement in the questionnaire was classified as "Realist", "Has Merit", and "Naïve". The data obtained were analyzed on each item using a frequency distribution to the students' VNOST group. "Realist" VNOST is used as a good indicator of VNOST views. The results revealed that most students have VNOST at the "Has Merit" level, which means that students' views on the nature of science and technology are still lacking and need to be improved. For this reason, educators need to integrate science and technology in science learning in schools.
\end{abstract}

\section{Keywords: VNOST, NTSQ, Realist, Has Merit, Nä̈ve}

\section{INTRODUCTION}

Improving scientific literacy is the main goal of education throughout the world [1]. The success of a country in implementing education can be predicted one of which is by measuring the level of scientific literacy of students through the Program for International Students Assessment, better known as PISA. The concept of scientific literacy in PISA refers to a knowledge of both science and science-based technology, even though science and technology do differ in their purposes, processes, and products. Technology seeks the optimal solution to a human problem, and there may be more than one optimal solution. In contrast, science seeks the answer to a specific question about the natural, material world. Nevertheless, the two are closely related, and science-literate individuals are expected to be able and willing to engage in reasoned discourse, and make informed decisions, about both science and technology [2].

Based on the results of the PISA study from 2000 to 2015 , the acquisition of science literacy scores of Indonesian students was very low, and in 2015 placed Indonesia ranked 64th out of 72 OECD participating countries. In addition to the low rankings, around $55.48 \%$ of Indonesian students are only able to master a low level of scientific literacy, consisting of levels $1 \mathrm{a}$ and $1 \mathrm{~b}$ even below that [3]. This level is included in the nominal category, namely the lowest level of scientific literacy in which students can only remember the names of concepts or terms but cannot explain their meaning [4].

One way to optimize students' scientific literacy skills is by meaningful science learning that teaches mastery of science concepts in a wider field through the understanding of the Nature of Science [NOS] [5]. NOS is defined as the values and assumptions inherent in the development of scientific knowledge [6]. The development and understanding of NOS is an important component in the dimensions of scientific literacy $[7,8]$. Several studies have also revealed that there is a relationship between NOS and scientific literacy $[9,10]$. Understanding NOS means students understand how science and scientific knowledge have developed and can enhance students' scientific perceptions in understanding the technology that is developing at this time. Therefore, NOS is known for its importance in improving scientific literacy in science learning [11].

Besides NOS, the concern about technology in science learning according to Ferreira-Gauchía is only seen as applied science or the results of science taught after science learning takes place [12]. Even though education experts began to view the importance of including a discussion on Nature of Technology (NOT). The concept of NOS cannot be properly understood without regard to the role of technology [13]. NOT is related to te cynical characteristics of its philosophy both ontological, epistemological and axiological aspects so that a positive attitude from the society grows about the importance of technological involvement in science learning. This is done to balance the increasingly rapid and sophisticated technological developments with their involvement in learning. Therefore, students must understand NOT itself [14].

Referring to the old view of science and technology, both of them are two different and separate things but interconnected with each other [15]. Awareness of the importance of the right view between NOS and NOT is not 
science and technology. Before being used, the questionnaire was translated into Indonesian and validated by experts. Table 1 shows one of the items of questionnaire VNOST. science and technology classes. This is because both are abstract and difficult to define [12]. However, the abstractness of NOS and NOT cannot be used as an excuse to negate both contents in science learning [16]. Therefore, it is important for all of us to look for ways we can teach NOS and NOT without adding complexity and abstractness to science learning.

To overcome the difficulties in teaching NOS and NOT, the importance of the integration of science and technology in science learning in the classroom [16,17]. Regarding the relationship between the nature of science and technology (NOST), Tairab proposes four main aspects which are an important part of the knowledge of the nature of science and technology [14], namely the characteristics of science and technology, scientific goals and scientific inquiry, characteristics of scientific knowledge and scientific theory, and the relationship between science and technology.

Research with VNOST in learning shows that it can influence students' perceptions of technology not only as a product but also that technology is a process so students are motivated in learning science [12]. Therefore, in science learning, students must be trained to be able to recognize phenomena in technology and explain them scientifically.

Several studies related to VNOST have been conducted. One of the studies from Tairab which shows the importance of the perspective of educators and students of prospective educators on science and technology or the View of Nature of Science and Technology (VNOST) to improve students' scientific literacy [14]. In addition, a study conducted by Kusumah on pre-service teachers by providing a VNOSTcharged questionnaire showed the VNOST level of prospective chemistry teachers at the Has Merit level [18]. According to Tairab to support learning that connects science and technology, teachers must have relevant knowledge about the nature of science and technology (VNOST) first [14]. The competence of VNOST will enable teachers to be able to present their science lessons more attractive to students [19]. In addition to teachers, Sofiani has conducted research related to VNOST for middle school students [20]. The results revealed that generally junior high school students have inadequate views regarding the nature of science and technology. Research on high school students has not been done so in this study will reveal the initial VNOST of high school students. This will be taken into consideration before further research is conducted.

\section{MethoDS}

This research is the initial stage in didactic design research [21], namely the preconception analysis process needed to design a strategy for learning. Participants involved in this study were 196 students majoring in MIPA, one of the high schools in the city of Bandung, which was chosen randomly from class $\mathrm{X}$ to class XII. The questionnaire used was a modification of the Nature of Science and Technology Questionnaire (NTSQ) from Tairab [14]. It consisted of 8 items where items 1 to 7 require respondents to choose from one of the best responses from the response given and item 8 requires respondents to provide written views of the difference between
TABLE I. ONE OF THE ITEMS OF THE VNOST QUESTIONNAIRE

\begin{tabular}{|c|c|c|}
\hline $\begin{array}{l}\text { Aspects of } \\
\text { VNoST }\end{array}$ & Item Questionnaire & Category \\
\hline \multirow{8}{*}{$\begin{array}{l}\text { The } \\
\text { purpose of } \\
\text { science and } \\
\text { scientific } \\
\text { research }\end{array}$} & In your opinion, what does science aim at: & \\
\hline & $\begin{array}{l}\text { To make sure that what has been discovered } \\
\text { about the world is really true }\end{array}$ & Naïve \\
\hline & $\begin{array}{l}\text { To understand, explain and interpret the } \\
\text { continued change in nature and its } \\
\text { characteristics }\end{array}$ & Realistic \\
\hline & $\begin{array}{l}\text { To discover, collect and group facts about } \\
\text { nature. }\end{array}$ & Has Merit \\
\hline & To find ways to make people's lives better & Has Merit \\
\hline & Do not know & Naïve \\
\hline & $\begin{array}{l}\text { I do not have enough knowledge to make } \\
\text { choices }\end{array}$ & Naïve \\
\hline & $\begin{array}{l}\text { None of the above options are fits with my } \\
\text { views }\end{array}$ & $*$ \\
\hline
\end{tabular}

The options for each item are categorized as R "Realistic", HM "Has Merit", N "Naïve", * "Uncategorized" based on the procedure developed by Rubba and Harkness [22]. View "Realist" relate to the common view of science, the concept of science, and theories of science as a whole. View "Has Merit" only has certain sections in accordance with science, concepts, and theories of science or the views are still reasonable. View of the "Naïve" is not relevant to science, concepts, and scientific theory. "Uncategorized" option that is an option "none of the above options are suitable for my views". The data obtained were analyzed for each of the items using a frequency distribution to characterize the students' VNOST.

\section{RESULTS AND DISCUSSION}

The students' Views of Nature of Science and Technology are presented in table 2-4. Table 2 presents the views of students on science, the purpose of science, and scientific research. There are three items related to science, its aim, and scientific research.

TABLE II. PERCENTAGE OF RESPONDENTS' VIEWS ON WhAT IS SCIENCE, THE PURPOSE OF SCIENCE, AND SCIENTIFIC RESEARCH

\begin{tabular}{|l|l|l|l|l|}
\hline \multirow{2}{*}{$\begin{array}{c}\text { VNOST Questionnaire } \\
\text { Statements }\end{array}$} & \multicolumn{4}{c|}{ Students' View (\%) } \\
\cline { 2 - 5 } & Realistic & $\begin{array}{c}\text { Has } \\
\text { Merit }\end{array}$ & Nä̈ve & Uncategorized \\
\hline Science is ... & 37.24 & 55.10 & 7.65 & 0,00 \\
\hline $\begin{array}{l}\text { In your opinion, what does } \\
\text { science aim at ... }\end{array}$ & 51.02 & 38.78 & 9.69 & 0.51 \\
\hline $\begin{array}{l}\text { Why do you think scientists } \\
\text { do scientific research ... }\end{array}$ & 29.08 & 67.35 & 2.55 & 1.02 \\
\hline
\end{tabular}

On the item about the definition of science, $37.24 \%$ of students provide their views that science is a process of systematic investigation and produces knowledge. This view is a view that is considered by Rubba \& Harkness as a "Realistic" view (R) so that the answer shows the suitability of responses with a common view of science [22]. In addition, a total of 
TABLE III. PERCENTAGE OF RESPONDENTS' VIEWS ON TECHNOLOGY

$55.10 \%$ of students provide a reasonable view or ("Has Merit"/HM) about science of which science is the field of study that helps explain about the world around us, science is concerned with investigating the things that unknown and discover new things about the world, and science is a field of science such as biology, chemistry, and physics. This view can still be used in defining science but not fully in accordance with the common view of science. In addition, a total of $7.65 \%$ of students provided a view of science related to finding and using knowledge to create a better world. The view of less precise in defining science so it is categorized as "Naïve".

In the question of the purpose of science, the views of students dominated by views related to science goals are to understand, explain, and interpret sustainable changes from nature and its characteristics of $51.02 \%$. This view is a "Realistic" view $(\mathrm{R})$ and that view is consistent with the initial view that considers science as a process of investigation. In addition, a percentage of $38.78 \%$ is given by students who have a reasonable view ("Has Merit"/HM) about the purpose of science, namely to find new ways to make human life better and to find, collect and group facts about nature. However, as much as $9.79 \%$ of students gave an inappropriate view regarding the purpose of science, namely ensuring that what had been discovered about the world was the right thing. This view was included in the naïve category because the goal of science was not only to believe but to prove process by understanding, explaining, and interpreting the ongoing changes in nature and its characteristics which are "Realistic" views [22].

In the question of scientific research, students' views are dominated by a reasonable view of "Has Merit" of $67.35 \%$ which argues that the purpose of scientific research is to collect as much data as possible, and conclude a scientific law based on that data and to make something can help human life. This view is still acceptable, but it is necessary to affirm that the purpose of scientific research is to explain why various things can happen, not just to conclude an existing law. This view is a view that fits the general view of science and is a view that is categorized as "Realistic" [22]

Table 3 presents students' views on technology. As much as $65.82 \%$ of students have a view of "Has Merit", which argues that technology is the application of science that is useful for improving life and technology as objects, techniques, processes, and people relating to scientific instruments, devices, and instruments. Both of these views are not yet in accordance with the general view of technology where technology is not just an applied science of science or objects resulting from the application of science, but technology is a process of creating, designing, developing and testing objects such as devices, scientific instruments and instruments objects such as devices, equipment, and scientific instruments. This is the appropriate view of "Realistic" because it includes processes, objects, and benefits [22].

\begin{tabular}{|c|l|c|c|c|}
\hline $\begin{array}{c}\text { VNOST } \\
\text { Questionnaire } \\
\text { Statements }\end{array}$ & \multicolumn{4}{|c|}{ Students' View (\%) } \\
\cline { 2 - 5 } & Realistic & $\begin{array}{c}\text { Has } \\
\text { Merit }\end{array}$ & Nä̈ve & Uncategorized \\
\hline Technology is .... & 30.10 & 65.82 & 4.08 & 0.00 \\
\hline
\end{tabular}

Table 4 presents the views of students on the nature of scientific knowledge and scientific theory. There are two items related to the nature of scientific knowledge and scientific theory. On items related to the nature of scientific knowledge, $84.18 \%$ of students gave a "Realistic" view of which students viewed current scientific knowledge based on scientific perspectives, ideas, and interpretations of scientists from the past and scientific knowledge as collections well-organized facts. In addition, on items related to scientific theory, the views of students between "Realistic" and "Has Merit" are almost the same size. The "Realistic" view is given by students as the most appropriate interpretation and explanation that has been proven by scientists by looking at scientific theory and "Has Merit" views given by students by looking at scientific theory as a fact that has been proven through various experiments. Students still see confusion between scientific theory and scientific facts. A scientific theory is a fact before an experiment is carried out. It is necessary for educators to distinguish between theory, law, and facts in science.

TABLE IV. PERCENTAGE OF RESPONDENTS' VIEWS OF THE NATURE OF SCIENTIFIC KNOWLEDGE AND SCIENTIFIC THEORY

\begin{tabular}{|l|l|l|l|l|}
\hline \multirow{2}{*}{$\begin{array}{c}\text { VNOST } \\
\text { Questionnaire } \\
\text { Statements }\end{array}$} & Realistic & $\begin{array}{c}\text { Has } \\
\text { Merit }\end{array}$ & Nä̈ve & Uncategorized \\
\cline { 2 - 5 } & & & & \\
\hline $\begin{array}{l}\text { Which of the } \\
\text { following } \\
\text { statement about } \\
\text { scientific } \\
\text { knowledge would } \\
\text { match your } \\
\text { understanding of } \\
\text { scientific } \\
\text { knowledge! }\end{array}$ & 84.18 & 2.04 & 8.67 & 5.10 \\
\hline $\begin{array}{l}\text { A scientific } \\
\text { theory is .... }\end{array}$ & 39.80 & 41.84 & 15.82 & 2.55 \\
\hline
\end{tabular}

Table 5 presents the views of students on the relationship between science-technology-society. As much as $55.10 \%$ of students have a "Realistic" view of the relationship between science-technology-and society. The dominant view in the "Realistic" view is that on the one hand, science and technology influence society, but on the other hand the community also influences the development of science and technology. This shows an awareness of the three things science-technology-society that influence each other. As many as $41.84 \%$ of students gave a view that "Has Merit". This view is dominated by the view that science and technology often make our lives healthier, easier, and more comfortable. This view does not show the influence of society in science and technology or the influence of science and technology on society [22]. 
TABLE V. PERCENTAGE OF RESPONDENTS' VIEWS OF THE RELATIONSHIP BETWEEN SCIENCE-TECHNOLOGY-SOCIETY

\begin{tabular}{|c|l|c|l|l|}
\hline \multirow{2}{*}{$\begin{array}{c}\text { VNOST Questionnaire } \\
\text { Statements }\end{array}$} & \multicolumn{4}{|c|}{ Students' View (\%) } \\
\cline { 2 - 5 } & Realistic & $\begin{array}{c}\text { Has } \\
\text { Merit }\end{array}$ & Nä̈ve & Uncategorized \\
\hline $\begin{array}{c}\text { Circle all the statements } \\
\text { that you agree with: }\end{array}$ & 55.10 & 41.84 & 1.53 & 1.53 \\
\hline
\end{tabular}

\section{CONCLUSION}

Based on the findings, it can be concluded that most students have VNOST at the "Has Merit" level on views of the four categories: 1) views on science, science goals, nature of scientific research, 2) views on technology, 3) views on scientific knowledge, scientific theories and scientific discoveries, and 4) views on the relationship between sciencetechnology-society. These results reveal that students' views on the nature of science and technology are still lacking and need to be improved so it is important for educators to integrate science and technology in science learning.

For this reason, there needs to be an effort made by educators in directing students' views from "Has Merit" to "Realist" so that learning design is arranged based on the "Realist" view in each VNOST category. The VNOST-charged learning design should be able to synergize with aspects of the content according to the demands of the applicable curriculum, as well as aspects of the technology-charged context that are close to the lives of students.

\section{ACKNOWLEDGMENT}

Our gratitude goes to all of the student's as participants. Our gratitude to the team members from the VNOST group.

\section{REFERENCES}

[1] A. Laherto, Nanoscience Education For Scientific Literacy Opportunities And Challenges In Secondary School And In Out-OfSchool Settings (Dissertation), Helsinky: University of Helsinky, 2012.

[2] OECD, PISA 2015 Results Excellence and Equity in Education, Paris: OECD Publishing, 2016, P. 15.

[3] OECD, "PISA 2015 Results in Focus", New York: Columbia University, 2016.

[4] A.H. Odja and C.S. Payu, "Analisis Kemampuan Awal Literasi Sains Siswa Pada Konsep IPA", Prosiding Seminar Nasional Kimia, (September), pp. 40-47, 2014.

[5] S. Tala, "The Nature Of Technoscience (NOTS)", In M. . Clough, J. Olson, \& D. Niedeshauser (Eds.), The Nature of Technology, pp. 5184, 2013.
[6] A. Rampal, "Images of Science and Scientists: A Study of School Teachers' of Scientists. International Science Education”, vol. 76, no. 4, pp. 415-436, 1992.

[7] Y. Shwartz, R. Ben-Zv and A. Hofstein, "The importance of involving high-school chemistry teachers in the process of defining the operational meaning of chemical literacy", International Journal of Science Education, vol. 27, no. 3, pp. 323-344, 2005.

[8] V.M. Vesterinen, Nature of Science for Chemistry Education, (Helsinky: Academic Dissertation, University of Helsinki), 2012, p. 1.

[9] N.G. Lederman, "Nature of Science: Past, Present and Future" (Mawah, NJ: Lawrence Erlbaum), vol. 28, pp. 831-835, 2006.

[10] N.G. Lederman, J.S. Lederman and A. Antink A, "Nature of Science and Scientific Inquiry as Contexts for the Learning of Science and Achievement of Scientific Literacy", International Journal of Education in Mathematics, Science and Technology, vol. 1, pp. 138-147, 2013.

[11] H. Park, Understanding Of The Nature Of Science: A Comparative Study Of Canadian And Korean Students (Dissertation). Toronto: University of Toronto, 2012.

[12] G.W. Fernandes, A.M. Rodrigues, and C.A. Ferreira, "Conceptions of the Nature of Science and Technology: a Study with Children and Youths in a Non-Formal Science and Technology Education Setting", Research in Science Education, vol. 48, no. 5, pp. 1071-1106, 2017.

[13] S. Tala, "The Nature Of Technoscience (NOTS). In M. . Clough, J. . Olson, \& D. . Niedeshauser (Eds.)", The Nature of Technology, Rotterdam: Sense Publisher, pp. 51-84, 2013.

[14] H.H. Tairab, "How do Pre-service and In-service Science Teachers View the Nature of Science and Technology?", Research in Science \& Technological Education, vol. 19, no. 2, pp. 235-250, 2001.

[15] R.W. Bybee and B. Fuchs, "Preparing the 21st Century Workforce: A New Reform in Science and Technology Education", Journal of Research in Science Teaching, vol. 43, no. 4, pp. 349-352, 2006.

[16] S. Tala and V.M. Vesterinen, "Nature of Science Contextualized: Studying Nature of Science with Scientists", Science and Education, vol. 24, no. 4, pp. 435-457, 2015.

[17] S. Tala, "A unified view of science and technology for education: Technoscience and technoscience education", Science and Education, vol. 18, no. 3-4, pp. 275-298, 2009.

[18] D.C. Kusumah, "Pre-service chemistry teachers' VNOST and their conceptions about the context of OLED and related chemistry contents", J. Phys.: Conf. Ser. 1157 042037, 2019.

[19] P. Ankiewicz, "Handbook of Technology Education. Handbook of Technology Education, pp. 1-15, 2016.

[20] D. Sofiani, Mudzakir, A. Hernani, "Examining Junior High School Students' Views Of The Nature Of Science And Technology", International Journal of Advances in Science Engineering and Technology, vol. 6, 2018.

[21] D. Suryadi, "Didactical Design Research (DDR) dalam Pengembangan Pembelajaran Matematika", Prosiding Seminar Nasional Matematika dan Pendidikan Matematika, vol. 1, 2013.

[22] P.A. Rubba and W.J. Harkness, "A new scoring procedure for the views on the science-technology-society instrument", International Journal of Science Education, vol. 18, no. 4, p. 387-400, 1996. 